\title{
DEFENDING SPACES, PREVENTING CONFLICTS The Politics of Identity Representation in the Nahdliyin Mosques in Malang Raya
}

Yulia Eka Putrie | UIN Maulana Malik Ibrahim Malang - Indonesia Widjaja Martokusumo | Institut Teknologi Bandung - Indonesia Bambang Setia Budi | Institut Teknologi Bandung - Indonesia Corresponding author: ekaputrie.yulia@arch.uin-malang.ac.id

\begin{abstract}
Contemporary dynamics among Islamic groups in Indonesia have affected aspects of Indonesian mosque architecture. One striking issue is the expropriation attempts against Nabdliyin mosques by certain groups deemed radical. The issue has drawn attention from the majority of Nabdliyin people through the Nahdlatul Ulama's official media. This study explores preventive actions taken by the Nabdliyin based on their shared-perspective towards the issue. Text and visual analyses are conducted based on the data of six chosen mosques in Malang Raya, East Java - a region with a great basis of the Nabdliyin, as well as the melting pot for various Islamic groups. The result shows that there are serious attempts of the surrounding communities to affirm their identity on their mosques. Iconographic and symbolic elements are applied to the mosque buildings to prevent mosques from being expropriated by other groups considered as hardliners. It further suggests an ambivalence where some pros and cons among the Nabdliyin themselves have occurred in terms of positive or negative impacts of the emergence of explicit identity on their mosques. Nevertheless, understanding the concept of shared-identity between a mosque and its surrounding community is an important basis to maintain peace and tolerance in the religious life of Muslim societies.
\end{abstract}

Keywords: Conflict prevention, identity representation, mosque architecture, Nahdlatul Ulama, Nabdliyin.

\section{Introduction}

Throughout history, the relationship between religious architecture and politics has taken form in various shapes and contexts. 
Architecture objects in many parts of the world have been used as the representation of political objectives, such as the show of power, glory, greatness, and authority. Regarding this, Oskar Verkaaik argues that religious buildings may not be crucial for religious reasons but are important in a social or political sense. ${ }^{1}$ The social and political significance of religious architecture is one of the main reasons of the great efforts of religious communities to build and preserve religious buildings all over the world. One of the most famous examples from the Classical Era was the construction of the Parthenon in Greece. Its magnificent architectural design seems to have succeeded in making it as an icon of Greek glory. Another example of the use of architecture objects for political objectives is the construction of Holocaust memorials in many countries to preserve Jewish people's collective memories on the historic episode. Popescu stated, "Constructed under the direct guidance of power and culture, the images of identity are forged through the intimate collaboration of ideology and aesthetics" 2 .

The similar phenomena occur in the religious architecture of the Muslim world. Historically, the development of mosque architecture throughout the world has recorded various political considerations which had influenced the design and construction of mosques. In the period of the Prophet Muhammad (pbuh), the establishment of Masjid Nabawi in Medina was considered as a unifying symbol of the Mubajirin and the Ansar. Less than a decade later, the Masjid Dhirar which had been established near Masjid Quba was mentioned in the

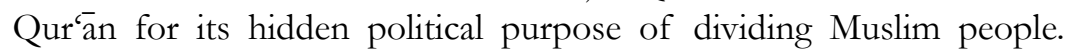
Therefore, the mosque was immediately torn down by the Muslims themselves. Afterwards, in the Muslim dynastic periods, various political objectives also underpinned the design and the construction of mosques. Many patrons were motivated to build mosques as symbols of political or dynastic power, or of the presence of the ruling power in a land conquered by the forces of Islam. ${ }^{3}$ The minarets which were established with various styles and heights in Masjid al-Azhar in Cairo, Egypt were clear evidents of these political objectives within mosque design and construction. Another example

1 Oskar Verkaaik, Religious Architecture: Anthropological Perspectives (Amsterdam: Amsterdam University Press, 2013), p. 8.

2 Carmen Popescu, 'Space, Time: Identity,' National Identities, 8 (2006), p. 189.

3 Renata Holod and Hasan-Uddin Khan, The Mosques and the Modern World: Architects, Patrons, and Designs since the 1950s (London: Thames \& Hudson, 1997), p. 23. 
from Muslim dynastic era was the mosques of the Ottoman which "reflected the changing identities and competing ambitions of various Muslim principalities". ${ }^{4}$

In the contemporary world, these political objectives remain influential to mosques' design and construction. Şimşek, Polvan, and Yeşilşerit's study about mosques in Turkey shows that two controversial mosque projects in Istanbul reflected the Islamists' desire for legitimacy, power, and prestige. ${ }^{5}$ Meanwhile, Ismail and Rasdi's study maintains the influence of political ideology on the architectural form of state mosques in Malaysia. ${ }^{6}$ Furthermore, Roose's study on community mosques in Netherland suggests the role of architectural preferability of the religious authorities in directing the concept and outcome of the mosque's design by architects. ${ }^{7}$ These studies send an important message that mosque architecture is influenced by various aspects, one of which is the socio-political aspect, beyond its functional aspect as a place of worship for the Muslims.

In the context of mosque development in Indonesia, each period suggests various political objectives lie within mosques' design and construction. At the time of the Wali Sanga, the adaptation of local culture was one political strategy for the mosques to be easily accepted by local people who have just embraced Islam. In the Colonial period, another form of political objective can be recognized in the construction of Masjid Agung Baiturrahman in Aceh by the Dutch colonial government. The mosque was rebuilt in 1877 after the original mosque was destroyed by the colonial government in order to rule the Sultanate of Aceh. ${ }^{8}$ It was rebuilt in a completely different

\footnotetext{
4 Gulru Necipoglu, "Anatolia and the Ottoman Legacy," in Martin Frishman and Hassan-Uddin Khan (eds), The Mosque: History, Architectural Development \& Regional Diversity (London: Thames \& Hudson, Ltd, 1994), p. 141.

5 Sefa Şimşek, Zerrin Polvan, and Tayfun Yeșilşerit, "The Mosque as a Divisive Symbol in the Turkish Political Landscape," Turkish Studies, 7, 3 (2006), p. 489.

6 Alice Sabrina Ismail and Mohd. Tajuddin Mohd Rasdi, "Mosque Architecture and Political Agenda in Twentieth-Century Malaysia," Journal of Architecture, 15, 2 (2010), p. 137.

7 Eric Roose, The Architectural Representation of Islam; Muslim-Commissioned Mosque Design in the Netherlands (Amsterdam: ISIM/Amsterdam University Press, 2009), p. 280.

8 Hugh O'Neill, "Diadem or Dome: Sovereignty and Transformation of the Mosque in Sumatera," in Tectonic Dimension in Islamic Architectural Tradition in Indonesia, Proceedings

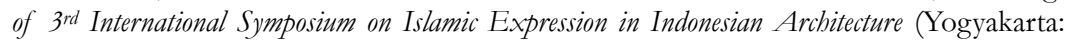


architectural style from the original mosque and any other mosques in Aceh. O'Neill stated, “The palaces and mosques of the rulers of Aceh and North Sumatera are a very visible result of the craving for power of the outsiders". 9 This illustrates the great desire of the Dutch colonial government to intervene the lives of the Muslim people through their mosques.

In the post-independence period, political objectives in Indonesian mosque development can be observed in the construction of Istiqlal Mosque. According to Abidin Kusno, Istiqlal Mosque which has became an icon of Indonesian Muslims, was inseparable from the political objective of President Soekarno to represent "the beacons of the emerging nations". ${ }^{10}$ Another president of Indonesia, Soeharto, during his 32 years of reign, has built many mosques with a 'standardized' design through the Amal Bhakti Pancasila Foundation. ${ }^{11}$ These mosques were seen as the representation of certain political ideology reframing the relationship between Islam and Indonesia.

On the other hand, beside the grand mosques which were built by the government, majority of mosques in Indonesia were actually built by various Islamic groups and their affiliated communities. The beginning of the $20^{\text {th }}$ century in Indonesia can also be seen as the beginning of the organizational establishment of various Indonesian Islamic groups, such as Muhammadiyah, Nahdlatul Ulama (NU), Persatuan Islam (Persis), and Al-Irsyad. Each group has certain ideals on mosque architecture based on their religious views and perspectives. These different views have led to differences in the preference of some physical and non-physical aspects, and were represented in certain elements of their respective mosques. Some elements have become the objects of disagreement among these groups, such as the use of bedug (an instrumental piece made of woods with leather covers on its left and right sides) and rich ornaments, the spatial division between men and women, and the existence of graves in the mosque's site. Moreover, these differences have also led to dynamic interactions

Department of Architecture, Faculty of Civil Engineering and Planning Islamic University of Indonesia, 2000), p. 22.

9 Ibid., p. 18.

10 Abidin Kusno, Behind the Postcolonial: Architecture, Urban Space and Political Cultures in Indonesia (New York: Routledge, 2000), p. 1.

11 Josef Prijotomo, Dari Lamin dan Bilik Pengakuan Dosa (Surabaya: Wastu Lanas Grafika, 2004), p. vii. 
between groups in relation to the mosque's significance as the symbol of idealism, legitimacy, and authority. Regarding this, Abidin Kusno argued that mosque architecture in Indonesia has become "the site of negotiation between the global pan-Islamic Islam and the Javanese world". ${ }^{12}$

In the last decade, the self-image appears even sharper in some Nabdliyin (lit. members of NU) mosques, particularly in East Java, Indonesia. Their identity as the Nabdliyin and their affiliation to NU are being explicitly represented in their mosques with the use of some iconographic elements such as the logo of the organization as the permanent ornaments on the building façades. For years, the distinctive characteristics in the Nabdliyin mosques were rather implicit and conotative than explicit and denotative. People used to distinguish the Nabdliyin mosques from the Modernist Muslim's mosques by the occurrence of some cultural elements such as bedug and throne-shaped minbar. The preference to use these implicit elements of identity was due to the initial function of mosque to serve all Muslims regardless of their groups or preferences.

However, it appears that nowadays they need more explicit and permanent architectural elements to represent their mosques' identity and to connect it with their own identity as the Nabdliyin. These phenomena of explicit identity representations in Nabdliyin mosques has led to some questions on their pattern of occurrence as well as their socio-political backgrounds. There are indications that the Nabdliyin's efforts to declare their identity in their mosques are not merely driven by ideological reasons, but rather by some political reasons. Thus, this study aims to explore the backgrounds and the pattern of the explicit and implicit elements of identity representation in the Nabdliyin mosques in Malang Raya (or Greater Malang), East Java, Indonesia.

Based on a qualitative research approach, this paper explores the phenomena of identity representations in Nabdliyin mosques in Malang Raya, East Java. East Java is known as the historical and cultural basis of the Nabdliyin since NU was first established in Surabaya, the capital

\footnotetext{
12 Abidin Kusno, “The Reality of One-which-is-Two"” - Mosque Battles and Other Stories: Notes on Architecture, Religion, and Politics in the Javanese World," Journal of Architectural Education, Vol. 57, No. 1 (2003), p. 57; Muh. Saerozi, "From Controversi to Tolerance; Dynamics of the Development of Istiqomah Mosque in Front of a Church in Ungaran Central Java Indonesia," Journal of Indonesian Islam, 11, 2 (2017), pp. 423-458.
} 
of this province, in 1926. Malang Raya is a sub-culture region in East Java consists of three administrative regions: Kabupaten Malang (or Malang Regency), Kota Malang (or Malang City), and Kota Batu (or Batu City). Malang Raya is chosen as the location of the research because of its socio-political dynamics between the Nabdliyin and other Islamic groups' participants. The dynamic interaction is due to the significant roles of Malang Raya as the city of education and tourism, as well as the second largest city located at the heart of East Java. When this study began in 2014, the initial field observation throughout the cities in East Java found that the mosques in this region suggest the most obvious tendency of identity representation through various explicit and permanent architectural elements, long before other regions in East Java begin to show the similar tendency in the recent times. Another study by Rijal also mentions that in the middle of 2014 there are at least five mosques in Malang have become the site of the ISIS declaration. ${ }^{13}$

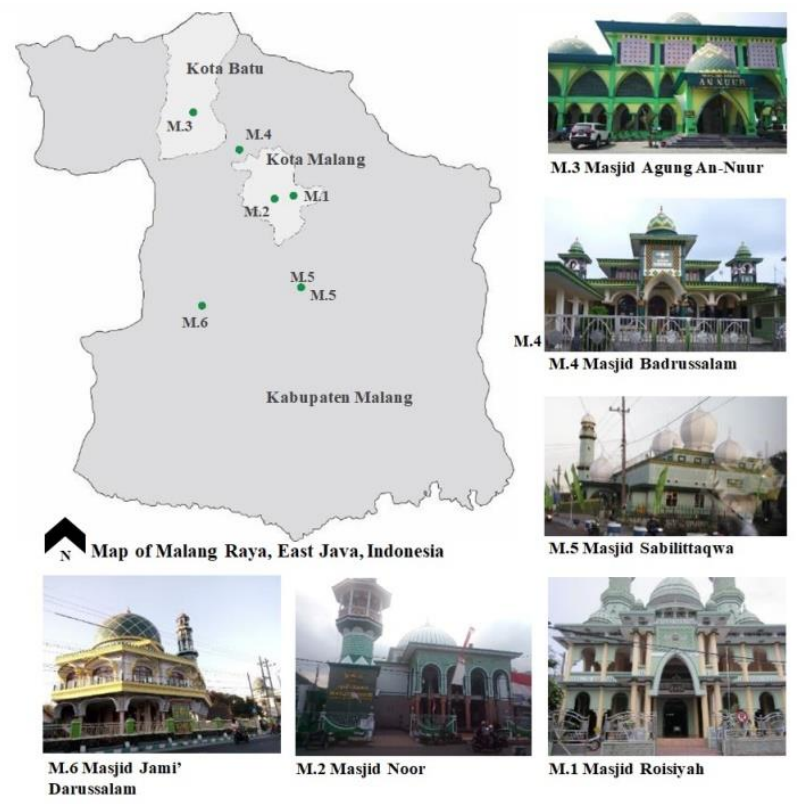

Figure 1. The location of six studied mosques in Malang Raya, East Java

13 Najamuddin Khairur Rijal, "Respons Pemerintah Lokal terhadap Ancaman Terorisme Global: Kasus ISIS di Kota Malang," Jurnal Global \& Strategis CSGS Unair Surabaya, 10 (2016), pp. 30-54. 
In this paper, six cases of Nabdliyin mosques with the most explicit and denotative elements of identity are analyzed based on the visual data from the field observation and documentation, as well as the text data derived from the semi-structured interview with the mosques' authority. These mosques are Masjid Roisiyah (M.1), Masjid Noor (M.2), Masjid Agung An-Nuur (M.3), Masjid Badrussalam (M.4), Masjid Jami' Sabilittaqwa (M.5), and Masjid Jami’ Darussalam (M.6) (Figure 1). All of them are vary in their scope of service. Masjid Roisiyah, Masjid Noor, and Masjid Badrussalam are the neighborhood mosques. Meanwhile, three other mosques are masjid jami' (district mosques) and masjid agung (grand mosques).

The visual analysis is focused on the elements of mosques' exterior, such as (1) the mosque's façade, (2) the mosque's overall scale and proportion, (3) the mosque's access and boundary, (4) the mosque's colors, (5) the iconographic ornaments' shape, position, scale, and proportion, (6) specific features of the Nabdliyin mosques, and (7) the mosques' position, site and setting. This limitation is due to the Nabdliyin's efforts to affirm the identity of their mosques which mainly focus on the mosques' exterior. The iconographic ornamentations found in these studied mosques are located on the exterior elements, such as the mosques' façade, the fence, and the gate. No explicit iconographic ornamentation displayed in the mosques' interior. However, from the text analysis of the interview data, there are some implicit elements as well as non-physical elements of identity representation in the interior space of these mosques, such as the spatial arrangement, and the ritual as well as non-ritual activities.

The local socio-political context of the studied mosques is another important part of this study. It was explored through text analysis on the semi-structured interview transcripts. The text analysis was conducted to reveal the backgrounds of the occurence of these explicit iconographic ornamentations and why they were situated on the exterior instead on the interior façades of the mosques.

\section{Strategies of Identity Representation in the Nahdliyin Mosques}

An initial observation in this study suggested that there are various strategies of identity representation in relation to the mosques' various local socio-political contexts and the characteristics of the communities. Among the strategies are the use of physical and nonphysical elements that show the efforts of non-verbal communication 
to represent the mosques' specific identity as the Nabdliyin mosques, such as name selection, activity system setting, role restrictions, preservation of specific cultural features, and utilization of audial instruments. In line with Kath Woodward statement that identities are marked symbolically and are reproduced through representational systems, ${ }^{14}$ this initial study found that there are six mosques with the most explicit and denotative elements of identity representations on their building exteriors. These mosques inidicate the most obvious tendency of identity representation through various explicit and permanent physical elements. Therefore, this paper focuses to discuss further these specific cases of mosques.

Table 1 shows the visual analysis of seven aspects of the building exterior in the six studied mosques. The similarities and differences of the physical elements of the mosques described in the table are important to find the pattern of the identity representation and its relationship with the mosques' local socio-political contexts. These patterns of difference and sameness, which are marked through representational systems, according to Woodward give meaning to how people see themselves and how others see them. ${ }^{15}$

Table 1. Visual analysis on the elements of mosques' exterior

\begin{tabular}{|c|c|c|c|c|c|c|}
\hline $\begin{array}{c}\text { Exterior } \\
\text { Elements }\end{array}$ & M.1 & M.2 & M.3 & M.4 & M.5 & M.6 \\
\hline \multirow[t]{2}{*}{$\begin{array}{l}\text { Exterior } \\
\text { Façade }\end{array}$} & & 新 & & & & \\
\hline & $\begin{array}{l}\text { Elaborated } \\
\text { with domes, } \\
\text { minarets, } \\
\text { excessive } \\
\text { ornamentation }\end{array}$ & $\begin{array}{l}\text { Elaborated } \\
\text { with a huge } \\
\text { dome, a } \\
\text { minaret, } \\
\text { exces-sive } \\
\text { ornamen- } \\
\text { tation, bright } \\
\text { colors }\end{array}$ & $\begin{array}{l}\text { Elaborated } \\
\text { with domes, } \\
\text { excessive } \\
\text { ornamentati } \\
\text { on, two } \\
\text { minarets at } \\
\text { the main } \\
\text { gate, bright } \\
\text { colors }\end{array}$ & $\begin{array}{l}\text { Elaborated } \\
\text { with domes, } \\
\text { small } \\
\text { minarets, } \\
\text { excessive } \\
\text { ornamentation, } \\
\text { bright colors }\end{array}$ & $\begin{array}{l}\text { Semi- } \\
\text { elaborated } \\
\text { with domes } \\
\text { and a } \\
\text { minaret }\end{array}$ & $\begin{array}{l}\text { Elaborated } \\
\text { with a huge } \\
\text { dome, a } \\
\text { minaret, } \\
\text { excessive } \\
\text { ornamentation, } \\
\text { bright colors }\end{array}$ \\
\hline
\end{tabular}

14 Kath Woodward, Understanding Identity (London: Oxford University Press Inc., 2002), p. xii.

15 Ibid., p. xiii. 
Putrie, Martokusumo, and Budi

\begin{tabular}{|c|c|c|c|c|c|c|}
\hline $\begin{array}{c}\text { Exterior } \\
\text { Elements }\end{array}$ & M.1 & M.2 & M.3 & M.4 & M.5 & M.6 \\
\hline Colors & $\begin{array}{l}\text { Light green } \\
\text { and yellow }\end{array}$ & $\begin{array}{l}\text { White and } \\
\text { green }\end{array}$ & $\begin{array}{l}\text { Green and } \\
\text { yellow }\end{array}$ & $\begin{array}{l}\text { Green and } \\
\text { yellow }\end{array}$ & $\begin{array}{l}\text { Light green, } \\
\text { white, yellow }\end{array}$ & $\begin{array}{l}\text { Green and } \\
\text { yellow }\end{array}$ \\
\hline $\begin{array}{l}\text { Overall } \\
\text { scale and } \\
\text { proportion }\end{array}$ & $\begin{array}{l}\text { Distinctive } \\
\text { scale from its } \\
\text { surroundings, } \\
\text { symmetrical } \\
\text { balance }\end{array}$ & $\begin{array}{l}\text { Distinctive } \\
\text { scale from its } \\
\text { surroundings, } \\
\text { asymmetrical } \\
\text { balance }\end{array}$ & $\begin{array}{l}\text { Distinctive } \\
\text { scale from } \\
\text { its } \\
\text { surroundings, } \\
\text { asymmetrical } \\
\text { balance }\end{array}$ & $\begin{array}{l}\text { Similar scale } \\
\text { with its } \\
\text { surroundings, } \\
\text { symmetrical } \\
\text { balance }\end{array}$ & $\begin{array}{l}\text { Distinctive } \\
\text { scale from its } \\
\text { surroundings, } \\
\text { asymmetrical } \\
\text { balance }\end{array}$ & $\begin{array}{l}\text { Distinctive } \\
\text { scale from } \\
\text { its } \\
\text { surroundings } \\
\text { asymmetrical } \\
\text { balance }\end{array}$ \\
\hline $\begin{array}{l}\text { Access } \\
\text { and } \\
\text { boundary }\end{array}$ & $\begin{array}{l}\text { Transparent, } \\
\text { low fence; one } \\
\text { main entrance }\end{array}$ & $\begin{array}{l}\text { Transparent, } \\
\text { tall fence; } \\
\text { two main } \\
\text { entrances }\end{array}$ & $\begin{array}{l}\text { Transparent, } \\
\text { tall fence; } \\
\text { one main } \\
\text { entrance } \\
\text { with a gate }\end{array}$ & $\begin{array}{l}\text { Transparent, } \\
\text { low fence; one } \\
\text { main entrance }\end{array}$ & $\begin{array}{l}\text { Transparent, } \\
\text { low fence; } \\
\text { one main } \\
\text { entrance } \\
\text { with a gate }\end{array}$ & $\begin{array}{l}\text { Transparent, } \\
\text { low fence; } \\
\text { two } \\
\text { entrances }\end{array}$ \\
\hline
\end{tabular}

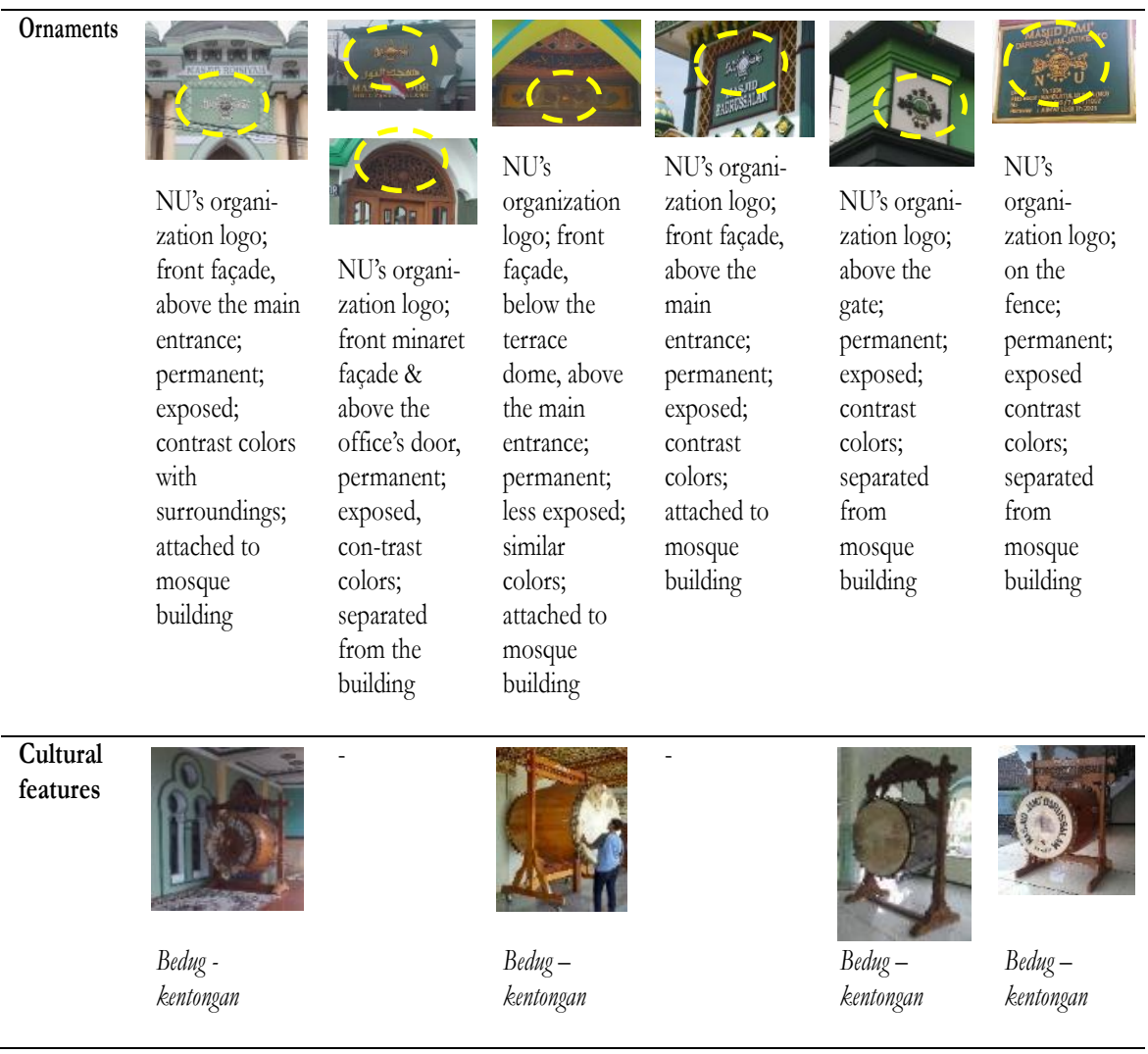




\begin{tabular}{|c|c|c|c|c|c|c|}
\hline $\begin{array}{c}\text { Exterior } \\
\text { Elements }\end{array}$ & M.1 & M.2 & M.3 & M.4 & M.5 & M.6 \\
\hline $\begin{array}{l}\text { Position, } \\
\text { site, and } \\
\text { setting }\end{array}$ & $\begin{array}{l}\text { Situated } \\
\text { adjacent to its } \\
\text { surrounding } \\
\text { settlement }\end{array}$ & $\begin{array}{l}\text { Situated } \\
\text { adjacent to } \\
\text { its } \\
\text { surrounding } \\
\text { settlement \& } \\
\text { business area }\end{array}$ & $\begin{array}{l}\text { Quite distant } \\
\text { with its } \\
\text { surrounding } \\
\text { settlement \& } \\
\text { business area }\end{array}$ & $\begin{array}{l}\text { Situated } \\
\text { adjacent to its } \\
\text { surrounding } \\
\text { settlement }\end{array}$ & $\begin{array}{l}\text { Situated } \\
\text { adjacent to } \\
\text { its } \\
\text { surrounding } \\
\text { settlement \& } \\
\text { business area }\end{array}$ & $\begin{array}{l}\text { Situated } \\
\text { adjacent to } \\
\text { its } \\
\text { surrounding } \\
\text { settlement }\end{array}$ \\
\hline
\end{tabular}

From the Table 1, one can conclude that the most significant elements of identity representation are the use of iconographic colors and iconographic ornaments as the dominant features of mosques' exterior. Iconographic colors displayed in these mosques are mostly varied greens and yellows. Sudjic stated the importance of color for built form. He argued that colors may indirectly provide functional alibis and signaling clues that define status or act as symbol of identity markers. ${ }^{16}$ According to Meerwein, Rodeck, and Mahnke, "Colors serve as information, communication, and design materials. They communicate symbolic messages, they are markers of personal and group identity". ${ }^{17}$ However, despite the strong similarity in the use of the iconographic colors on the exterior of these mosques, the interviewees expressed their thoughts about the mosques' colors in various ways:

Question: Do colors signify the Nabdliyin mosques?
Answers:
"Yes, the colors are among the signifiers..." (M.1) $)^{18}$
"Indeed... The characteristics of NU's mosques... the color is usually green, it tends to be like that..." (M.5) ${ }^{19}$
"Oh no... The color is not always a dominant sign of NU's mosques, but clearly there might be a little bit of green, because

\footnotetext{
16 Deyan Sudjic, The Edifice Complex: How the Rich and Powerful Shape the World (London: Penguin Press, 2005), p. 131.

17 G. Meerwein, B. Rodeck, and F. H. Mahnke, Color - Communication in Architectural Space (Switzerland: Birkhäuser, 2007), p. 16.

18 The original version in Indonesian says: "Iya termasuk itu..." (M.1)

19 The original version in Indonesian says: "Yaa... biasanya itu ... kalau ciri-ciri daripada masjid NU itu, kalau masalah warna ya biasanya ijo, cenderung ke sana..." (M.5)
} 
the blue is conotated with Muhammadiyah (other group)..." $(\mathrm{M} .3)^{20}$

"No, no... the green is not a must..." (M.2) ${ }^{21}$

"Indeed... NU people usually use green... but it is a matter of taste... NU people commonly use green...” (M.6) ${ }^{22}$

The above statements indicates that the massive use of the specific colors on the mosques' façades was not a top-down instruction from the NU organization. It is more of a bottom-up initiative from the Nabdliyin themselves. It can be observed from the different range of greens and yellows used in the different mosques. A top-down instruction would have a higher degree of similarity in the iconographic colors used with the green and the white in the official logo and the flag of the organization (Figure 2). The use of iconographic colors such as green, white, and yellow (golden) as the signifiers for the Nabdliyin mosques are considered as part of habitudes (M.3, M.5, M,6), tendencies (M.5), and preferencies (M.6) of the community, not as part of structured rules or formal conventions (M.2) of the organization.
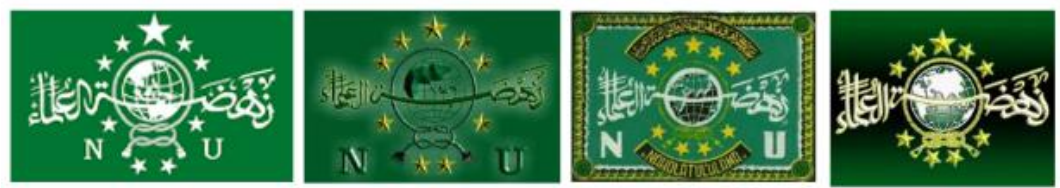

Figure 2. The official logo (left) and various un-official logos of the Nahdlatul Ulama ${ }^{23}$

The dominant use of green, white, and yellow in the Nabdliyin mosques is identical with the use of those colors in various forms of the Nabdliyin's cultural media such as the webs, the brochures, and the

20 The original version in Indonesian says: "Oh ndak, warna tidak begitu mendominasi babwa iki mesjide wong NU, tapi yang jelas mungkin ada warna ijo dikit ya, lek biru kan konotasi Mubammadiyah..." (M.3)

21 The original version in Indonesian says: "Ndak, kalo warna ndak... ndak harus bijau gitu lho..." (M.2)

22 The original version in Indonesian says: "Nah... kalo biasanya kalo NU itu kan biasa ijo... ijo... tapi itu kan termasuk selera... yang memang kalo, kalo NU itu kan motifnya kan ratarata kan hijau..." (M.6)

23 Sources: Various websites of the Nabdliyin. 
events' decoration (Figure 3). These iconographic colors can be considered as an element of the Nabdliyin's visual culture. One form of the Nabdliyin's creative campaigns is even mentioning green as the symbol of the calming characteristics of NU, "Yang ijo, emang bikin adem," or "The green one is truly calming," (Figure 3a). Another campaign used the word 'JAS HIJAU' (green jacket) as an abbreviation of 'Jangan Sekali-kali Hilangkan Jasa Ulama' or 'Never Dismiss the Legacy of the Muslim Scholars' (Figure 3d). The statement that green represents NU and blue represents Muhammadiyah (M.3) is also found in another form of the creative campaign (Figure 3c).
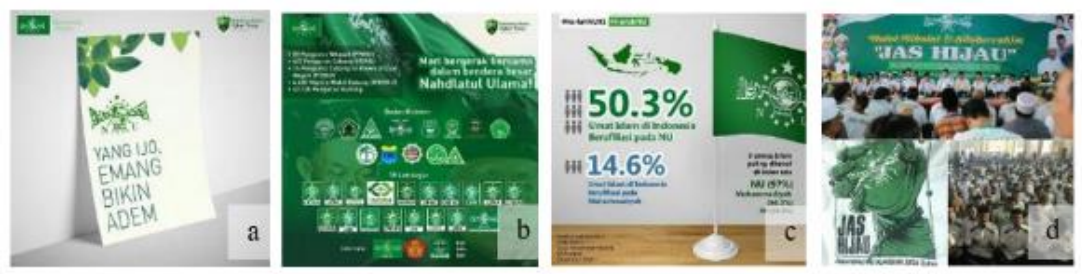

Figure 3. Various forms of creative campaign of the Nabdliyin in the social media $^{24}$

Along with the massive use of the iconographic colors, the prominent use of the NU's logo as a permanent iconographic ornament is also found on the exterior elements of the six studied mosques. Almost all of these iconographic ornaments are exposed at the main area of mosques' exterior, with big size and contrast colors from their backgrounds. Some iconographic ornaments are placed on the main building façades, while some others are places on the fence, the minaret's wall, and the main gate. In particular, one of the mosques (M.3) shows a different tendency by placing its iconographic ornament below the terrace dome with the similar colors with its background, therefore less exposed from the mosque's surrounding environment.
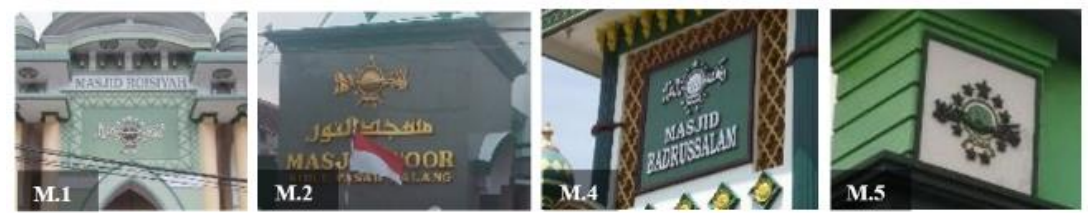

24 Source: Instagram account of @nahdlatululama, 2017. 

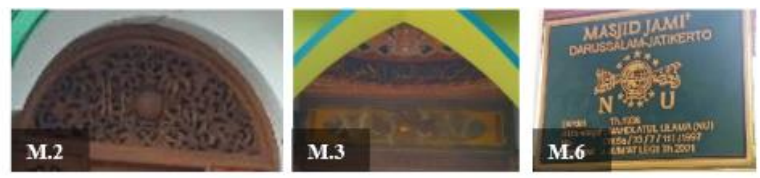

Figure 4. Various forms of iconographic ornament on the exterior elements of the mosques

Some of the iconographic ornaments are placed above or below the name of the mosques (Figure 4). This pattern of placement suggests the sense of authority of the Nabdliyin in the studied mosques. However, despite the eagerness to show the authority through the iconographic ornaments, only one mosque (M.6) which clearly includes the letters 'NU' in its iconographic ornament, as it appears on the official logo of $\mathrm{NU}$, while the other mosques have chosen not to include the letters on their ornaments. This phenomenon indicates the efforts to reduce the explicitness of the iconographic ornaments. It shows an ambivalence or dilemmas between an urge to represent the specific identity of the mosques and an unwillingness to make others think of the mosque as confined to the Nahdliyin only. They wanted to show their communal authority of the mosques, yet they did not want to keep others away from the mosques.

Furthermore, in contrast with their iconographic exteriors, the interiors of the mosques are not designed with any explicit iconographic element. A wide variety of colors are used and no permanent iconographic ornament (the logo of $\mathrm{NU}$ ) are placed in the interior. This phenomenon indicates that there are hesitations to place the organization logo inside the main prayer spaces due to the protection of the prayer spaces from any worldly matters. It also indicates that the efforts to represent identity is more intended for the outsiders rather than for the local communities themselves.

Another significant element of identity representation are the use of specific features such as bedug and kentongan (lit. an instrumental piece made of bamboo) as well as the elaborated façades as the implementation of their specific view towards beauty and ornaments. These specific features of the Nabdliyin mosques are a form of nonverbal communication to show distinction and resistance from another Islamic groups' views which have rejected the features in their mosques. However, the deeper comprehension about these specific features and their significance in representing identity of the Nabdliyin 
mosques requires a further study, because despite the importance of the symbolic cultural elements such as bedug and kentongan in the perspective of the Nabdliyin, their existence in the studied mosques is not as significant as the iconographic colors and ornaments. These elements can be found in four of the six studied mosques. The other two mosques have not had any bedug and kentongan due to some pragmatic reasons. One of the studied mosques (M.1) just had its bedug and kentongan recently after the absence of these cultural elements since the mosque was massively renovated in 2006.

Moreover, the overall scale, the limited access, and the use of fence as a boundary in these mosques are also another form of non-verbal communication to show restriction, authority, and territoriality. As Oleg Grabar noted in one of his article, that despite their social function, in certain context religious monuments such as mosques often reflect the expression of power in some fashion. ${ }^{25}$ The existence of fences as the barrier between the mosques' sites and their surroundings suggests that regardless their status as a public building, the mosques are still 'owned' by certain authorities governing and managing every aspects of these mosques. As Kath Woodward noted that the formation and establishment of identity involves both locating and transgressing boundaries, ${ }^{26}$ these studied mosques established their boundaries through the use of the fences and gates with the iconographic elements (especially in M.5 and M.6) to communicate their authorities and territorialities (Figure 5).
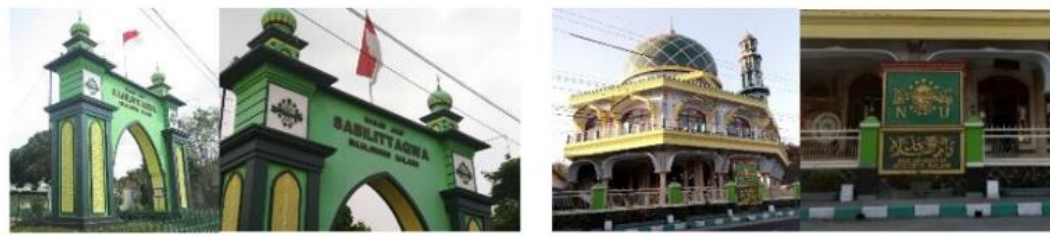

Figure 5. The use of iconographic elements in the gate and the fence of M.5 (left) and M.6 (right)

However, the height and the visual transparency of the fences also communicate that these mosques are not fully restricted due to their

25 Oleg Grabar, "The Architecture of Power: Palaces, Citadels, and Fortifications," in George Michell (ed.), Architecture of the Islamic World: Its History and Social Meaning (London: Thames \& Hudson, 1978).

26 Woodward, Understanding Identity, p. xii. 
function to serve the wider circles of Muslim people. The adjacency of the mosques' buildings with their surroundings also communicates that eventhough these mosques have distinctive scale from their surroundings, they still belong to their communities. Along with the ambivalent use of iconographic colors and ornaments, this phenomenon also shows the complex considerations between an urge to control the mosques and an unwillingness to push other people away from the mosques. There is a kind of communal authority to manage activities in the mosques where other people can enter and do permitted activities in the mosques. However, these other people have a restricted role as guests and the Nabdliyin themselves act as the host of the mosques. In other words, there are role restrictions through non-verbal communications which have to be understood by all parties in the mosques. Further analysis on the semi-structured interview texts was conducted to explore the backgrounds of these role restrictions and ambivalences in identity representation phenomena.

\section{Identity Representation and Conflict Prevention: Defending Spaces through Non-Verbal Communications}

The result of the visual analysis of the six Nabdliyin mosques studied here shows that there are explicit efforts of identity representation mainly through the iconographic colors and ornaments which dominate the exterior of the mosques. However, there are ambivalences between the need to declare the specific identity of the Nabdliyin in their mosques, and the hesitation or concern of unintentionally making the mosques exclusive and forbidden to others. Therefore, it is interesting to explore the backgrounds of the occurrences of the identity representation phenomena in these studied mosques. Identity, according to Kath Woodward, clearly matters. However, in order to make sense of identity, the social circumstances needs to be investigated. ${ }^{27}$ These phenomena of identity representations in the studied mosques indicate a strong relationship between the needs to represent identity through some physical elements and the dynamics of their socio-political contexts.

The interview with the significant stakeholders of these Nabdliyin mosques (the mosques' caretakers and the local figures of the Nabdliyin) had been conducted to explore the backgrounds of these

27 Ibid., p. x; Syamsul Rijal, "Friday Prayer and an Indonesian Islamic Identity in Canberra, Australia," Journal of Indonesian Islam, 3, 1 (2009), pp. 148-167. 
phenomena of identity representations. The analysis on the interview texts showed that identity representations through architectural elements of the mosques are one of the preventive efforts of these stakeholders to avoid the mosques from the seizing efforts or the expropriation attempts by an Islamic group considered radical by the Nabdliyin. Below are the important statements of the mosques' stakeholders:

"The imam, muezzin, and khatib are already licensed, they cannot be chosen carelessly. Indeed, once, there was someone who came from Jakarta, asked permission to stay in the mosque, it turned out that he and his (speech) contents are very contradictory (to our values). So, many people protested him at that time, in short, we overlooked (the control over the mosque)..." (M.1) ${ }^{28}$

"Here we have a foundation... however, culturally, the power, i mean the greatest influence, belongs to NU... this mosque is NU's mosque. Before the other mosques dare to 'wave flags' (declaring identity), this mosque has been labeled as the NU's mosque since the old times. In the year 1933, the congress of NU was held here... so it is impossible for us to 'change the flag' (shifting identity), no way... Here it is, in front of the mosque's office, there is the ornament of NU's logo..." (M.2) ${ }^{29}$

"In the future, if there is no signifier, many other groups can enter (the mosque). Nowadays many groups occupy mosques and mushollas, especially the less maintained ones, they get a place there... hence, the Islamic Law Council of this mosque, said that it is good, that the identity of this mosque were made clear... so that if other groups want to occupy this mosque, they already warned from a far, they will not get any closer, it's like that..." (M.3) ${ }^{30}$

\footnotetext{
28 The original version in Indonesian says: "Imam, muadzin, dan khotib itu sudab ada terijinnya, ngga boleh sembarangan. Memang dulu pernah sekali ada yang datang dari Jakarta, ..., ijin tinggal di masjid, ternyata yang datang bukan dia, jadi orang lain dan isinya sangat bertentangan. Jadi banyak yang protes waktu itu, singkat katanya kita kecolongan..." (M.1)

29 The original version in Indonesian says: "Eee selain ada yayasan, tapi di sini adalab NU yang punya kekuas... eh... punya pengarub besar, masjidnya ini masjid NU. Dulu masjid-masjid itu belum berani ada berkibarnya bendera, ya, masjid ini adalah sudah, labelnya sudah NU sejak dulu. Sejak dulu, babkan tahun 33 di sini itu putusan muktamar NU tabun 33 itu di sini... 33, $34 \ldots$ pernah... muktamar NU tho ya... jadi ndak mungkin kita pindah bendera, ndak mungkin... Di sini memang, di kantor itu, depannya itu ada lambang NU-nya..." (M.2)

30 The original version in Indonesian says: "Ke depan, kalau tidak ada ininya, banyak yang lain masuk. Sekarang kan gitu, ono jaulah-jaulah, masuk masuk kayak mesjid musholla, pokoke
} 
"If they want to perform the congregational prayers... and nowadays the background of the newcomers are various, $i$ do not intend to restrict them, go ahead... but i'm very sorry... back to the 'uniform', if they are not the NU people (the Nabdliyin), try not to be in the front (as the imam), if they want to be the makmum (the followers of congregational prayers) that's okay... everyone can enter the mosque, LDII, Muhammadiyah, even the Salafi..." $(\mathrm{M} .4)^{31}$

"People said that we should display the logo of NU, so that other people realize that this mosque was built by NU's people (the Nabdliyin), because... if not... in the future... well, others might... (occupy the mosque),") (M.5) ${ }^{32}$

"From the beginning this mosque belongs to NU ahlussunnah wal jamaah... however, there are some 'guests' who have a different belief system (aqidah)... Wahhabi or something like that i don't know for sure... they come to this mosque frequently... nevertheless, all of the mosque's caretakers let them in 24 hours a week, as long as they don't take part in managing or ruling the mosque... we don't want it to happen, that's not permitted..." $(\text { M.6) })^{33}$

ndek kono nggak begitu dirawat, ya dek'e mendapat tempat di situ... ya... makanya wis... langsung, Dewan Abkam, sudah, bagus itu, identitas biar jelas, bila ada orang lain mau masuk, ob sono NU... biar ga dekat. Kan gitu ya..." (M.3)

31 The original version in Indonesian says: "Nek jamaab tho nggih...dan sekarang latar belakang pendatang niku macem macem, nek kulo mboten batesi, silabkan...tapi maaf maaf ini mbalik nang kelambi maneh, memang kalo di luar NU coba jangan di depan (ngimami maksudnya), nek makmum monggo. Koyok LDII mlebuo, Muhammadiyah mlebuo, sing celono cingkerang mlebuo." (M.4)

32 The original version in Indonesian says: "Katanya orang-orang wis kasib aja lambang NU, biar tau kalo ini masjid yang didirikan oleh warga NU, sebab eee... kalo ndak gitu nanti, anu... ya seperti ada yang eee...” (M.5)

33 The original version in Indonesian says: "Wah kalo di sini itu anu... kalo di sini itu mulai dulu memang NU ablussunnah wal jamaah... ya memang ada 'tamunya' itu, istilabnya itu sekarang itu anu, ya ada 'tamu' yang... istilabnya... rupanya... akidah yang begini itu tho... wabhabi apa gitu... saya ndak, ndak, tabu persis, pokoknya yang akidahnya itu... memang, memang di sini itu anu... eeh... agak, agak didatangi orang seperti itu... di sini itu... tetapi... yaa... pengurus semuanya ini ya... ya ngga apa-apa biarin aja kalau... kalau apa itu... orang apa itu istilahnya, lain akidah, monggo silakan 24 jam, cuma kalo masuk atau mengatur itu memang ndak diinginkan, ndak boleh..." (M.6) 
Table 2 is the text analysis of the interview transcripts of the six studied mosques. The analysis underpinned the backgrounds, the context, the strategies, and the objectives of the identity representations in the studied mosques.

Table 2. Text analysis on the phenomena of the identity representations in the studied mosques

\begin{tabular}{|c|c|c|c|c|}
\hline $\begin{array}{l}\text { Mosque's } \\
\text { Code }\end{array}$ & $\begin{array}{l}\text { Backgrounds of } \\
\text { the Identity } \\
\text { Representations }\end{array}$ & Context & Strategies & $\begin{array}{c}\text { Objectives of } \\
\text { the Identity } \\
\text { Representations }\end{array}$ \\
\hline M.1 & $\begin{array}{l}\text { The awareness } \\
\text { ofthe issue and } \\
\text { experience of } \\
\text { direct conflict } \\
\text { with outsiders } \\
\text { trying to infiltrate } \\
\text { the mosque }\end{array}$ & $\begin{array}{l}\text { Historical } \\
\text { context, } \\
\text { socio-cultural } \\
\text { context }\end{array}$ & $\begin{array}{l}\text { Physical: } \\
\text { Iconographic } \\
\text { elements (colors } \\
\text { and ornaments), } \\
\text { maintaining cultural } \\
\text { elements (minbar } \\
\text { design, spatial } \\
\text { arrangement) } \\
\text { Non- } \\
\text { physical:maintaining } \\
\text { ritual and non-ritual } \\
\text { traditions, role } \\
\text { restrictions }\end{array}$ & $\begin{array}{l}\text { Defending space, } \\
\text { preventing } \\
\text { conflicts, } \\
\text { preserving and } \\
\text { keeping the } \\
\text { traditions from } \\
\text { the obliteration } \\
\text { by other group } \\
\text { deemed radical }\end{array}$ \\
\hline M.2 & $\begin{array}{l}\text { The awareness of } \\
\text { the issue and } \\
\text { experience of } \\
\text { direct conflict } \\
\text { with outsiders } \\
\text { trying to occupy } \\
\text { the mosque } \\
\text { without } \\
\text { permission }\end{array}$ & $\begin{array}{l}\text { Historical } \\
\text { context, } \\
\text { political } \\
\text { context, } \\
\text { socio-cultural } \\
\text { context }\end{array}$ & $\begin{array}{l}\text { Physical: } \\
\text { Iconographic } \\
\text { elements (colors } \\
\text { and ornaments), } \\
\text { maintaining cultural } \\
\text { elements (minbar } \\
\text { design, calligraphy) } \\
\text { Non-physical: } \\
\text { maintaining ritual } \\
\text { and non-ritual } \\
\text { traditions, role } \\
\text { restrictions }\end{array}$ & $\begin{array}{l}\text { Defending space, } \\
\text { preventing } \\
\text { conflicts, } \\
\text { preserving and } \\
\text { keeping the } \\
\text { traditions from } \\
\text { the obliteration } \\
\text { by other group } \\
\text { deemed radical }\end{array}$ \\
\hline M.3 & $\begin{array}{l}\text { The awareness of } \\
\text { the issue and } \\
\text { anticipation of } \\
\text { what might } \\
\text { happen in the } \\
\text { future with the } \\
\text { occurrence of }\end{array}$ & $\begin{array}{l}\text { Historical } \\
\text { context, } \\
\text { political } \\
\text { context, } \\
\text { socio-cultural } \\
\text { context, } \\
\text { internal }\end{array}$ & $\begin{array}{l}\text { Physical: } \\
\text { Iconographic } \\
\text { elements (colors } \\
\text { and ornaments), } \\
\text { maintaining cultural } \\
\text { elements (minbar } \\
\text { design, calligraphy, }\end{array}$ & $\begin{array}{l}\text { Defending space, } \\
\text { preventing } \\
\text { conflicts, } \\
\text { preserving and } \\
\text { keeping the } \\
\text { traditions from } \\
\text { the obliteration }\end{array}$ \\
\hline
\end{tabular}




\begin{tabular}{|c|c|c|c|c|}
\hline $\begin{array}{l}\text { Mosque's } \\
\text { Code }\end{array}$ & $\begin{array}{l}\text { Backgrounds of } \\
\text { the Identity } \\
\text { Representations }\end{array}$ & Context & Strategies & $\begin{array}{c}\text { Objectives of } \\
\text { the Identity } \\
\text { Representations }\end{array}$ \\
\hline & $\begin{array}{l}\text { many groups if } \\
\text { the mosque is } \\
\text { less maintained } \\
\text { or lack of identity } \\
\text { representation }\end{array}$ & $\begin{array}{l}\text { dynamics } \\
\text { (discussion, } \\
\text { hesitation, } \\
\text { disagreement) }\end{array}$ & $\begin{array}{l}\text { bedug) } \\
\text { Non-physical: } \\
\text { maintaining ritual } \\
\text { and non-ritual } \\
\text { traditions, role } \\
\text { restrictions }\end{array}$ & $\begin{array}{l}\text { by other group } \\
\text { deemed radical }\end{array}$ \\
\hline M.4 & $\begin{array}{l}\text { The awareness of } \\
\text { the issue and } \\
\text { anticipation of } \\
\text { other groups' } \\
\text { taking control of } \\
\text { the mosque }\end{array}$ & $\begin{array}{l}\text { Historical } \\
\text { context, } \\
\text { socio-cultural } \\
\text { context }\end{array}$ & $\begin{array}{l}\text { Physical: } \\
\text { Iconographic } \\
\text { elements (colors } \\
\text { and ornaments), } \\
\text { maintaining cultural } \\
\text { elements (minbar } \\
\text { design, calligraphy, } \\
\text { spatial arrangement) } \\
\text { Non-physical: } \\
\text { maintaining ritual } \\
\text { and non-ritual } \\
\text { traditions, role } \\
\text { restrictions }\end{array}$ & $\begin{array}{l}\text { Defending space, } \\
\text { preventing } \\
\text { conflicts, } \\
\text { preserving and } \\
\text { keeping the } \\
\text { traditions from } \\
\text { the obliteration } \\
\text { by other group } \\
\text { deemed radical, } \\
\text { maintaining } \\
\text { harmony with } \\
\text { other groups }\end{array}$ \\
\hline M.5 & $\begin{array}{l}\text { The awareness of } \\
\text { the issue and } \\
\text { anticipation of } \\
\text { other groups' } \\
\text { taking control of } \\
\text { the mosque }\end{array}$ & $\begin{array}{l}\text { Historical } \\
\text { context, } \\
\text { political } \\
\text { context, } \\
\text { socio-cultural } \\
\text { context }\end{array}$ & $\begin{array}{l}\text { Physical: } \\
\text { Iconographic } \\
\text { elements (colors } \\
\text { and ornaments), } \\
\text { maintaining cultural } \\
\text { elements (minbar } \\
\text { design, spatial } \\
\text { arrangement, } \\
\text { bedug) } \\
\text { Non-physical: } \\
\text { maintaining ritual } \\
\text { and non-ritual } \\
\text { traditions, role } \\
\text { restrictions }\end{array}$ & $\begin{array}{l}\text { Defending space, } \\
\text { preventing } \\
\text { conflicts, } \\
\text { preserving and } \\
\text { keeping the } \\
\text { traditions from } \\
\text { the obliteration } \\
\text { by other group } \\
\text { deemed radical }\end{array}$ \\
\hline M.6 & $\begin{array}{l}\text { The awareness of } \\
\text { the issue and } \\
\text { anticipation of } \\
\text { other groups' } \\
\text { taking control of } \\
\text { the mosque }\end{array}$ & $\begin{array}{l}\text { Historical } \\
\text { context, } \\
\text { socio-cultural } \\
\text { context }\end{array}$ & $\begin{array}{l}\text { Physical: } \\
\text { Iconographic } \\
\text { elements (colors } \\
\text { and ornaments), } \\
\text { maintaining cultural } \\
\text { elements (minbar }\end{array}$ & $\begin{array}{l}\text { Defending space, } \\
\text { preventing } \\
\text { conflicts, } \\
\text { preserving and } \\
\text { keeping the } \\
\text { traditions from }\end{array}$ \\
\hline
\end{tabular}




\begin{tabular}{|c|c|c|c|c|}
\hline $\begin{array}{c}\text { Mosque's } \\
\text { Code }\end{array}$ & $\begin{array}{l}\text { Backgrounds of } \\
\text { the Identity } \\
\text { Representations }\end{array}$ & Context & Strategies & $\begin{array}{c}\text { Objectives of } \\
\text { the Identity } \\
\text { Representations }\end{array}$ \\
\hline & & & $\begin{array}{l}\text { design, calligraphy, } \\
\text { spatial arrangement, } \\
\text { bedug) } \\
\text { Non-physical: } \\
\text { maintaining ritual } \\
\text { and non-ritual } \\
\text { traditions, role } \\
\text { restrictions }\end{array}$ & $\begin{array}{l}\text { the obliteration } \\
\text { by other group } \\
\text { deemed radical, } \\
\text { maintaining } \\
\text { harmony with } \\
\text { other groups }\end{array}$ \\
\hline
\end{tabular}

From the analysis in Table 2, one can comprehend that among the physical strategies taken are the use of the iconographic elements (colors and ornaments) as well as the symbolic cultural elements (minbar, calligraphy, spatial arrangement, and bedug) to represent their identity as the Nabdliyin mosques. Meanwhile, maintaining the ritual and non-ritual traditions (tablil, diba'an, and istighotsab) as well as establishing role restrictions for the outsiders are among the nonphysical strategies taken by the Nabdliyin mosques' stakeholders. This specific identity of their mosques were sometimes metaphorically expressed as their "uniform" (M.4) and their "flag" (M.2) to show the strong attachment between their mosques' identity and their own identity. Popescu stated, "Architecture and identity, individual and collective, appear to be intrinsically connected. This is true particularly for collective identities since groups identify themselves with the place in which they evolve". 34

The identity representation phenomena in the Nabdliyin mosques occur due to the awareness of the mosques' stakeholders on the issue of the seizing efforts or the expropriation attempts by an Islamic group considered radical by the Nabdliyin. This socio-political issue has arisen in the last decade in line with the phenomena of the shifting affiliation in many mosques as indicated in the NU's mass media. A discourse analysis on the raising of this issue in the NU's online media has been conducted separately to explore the significance of the issue from the perspective of the NU's organization and its affiliated communities. The result of the discourse analysis showed that the awareness of the issue in the level of community is strongly related to

34 Popescu, “Space, Time: Identity", p. 191. 
the awareness in the organizational and the national level. From 2006 to 2016, the NU's online media has actively spread the awareness and sought the involvement of the stakeholders at the level of community to prevent conflict due to the expropriation attempts on Nabdliyin mosques. Along with that, some stakeholders of the studied mosques have also experienced the direct conflicts in their own mosques with the other group. Thus, the awareness of the mosques' stakeholders was raised through their experiences as well as their references from the news.

In these studied mosques, the stakeholders' initiatives to start using the more explicit ways of identity representation were varied from 2006 (M.1) until 2016 (M.6). These phenomena of identity representation attempts were in accordance with the spreading issue in the media between 2006 and 2016 to raise the awareness of the NU people towards the physical conflicts in the form of the seizing attempts or the expropriation efforts by the other group deemed radical. In the eyes of the Nabdliyin, this radical group thought that the Nabdliyin mosques are full of new traditions with no example from the time of the Prophet Muhammad saw. Therefore, these people argued that the mosques should be purified from such traditions. This group's perspective has made the Nahdliyin mosques a site of challenge and it has caused the Nabdliyin communities consider the group as a threat to their mosques identity as an inseparable part of their own identity.

The strong relationship between the awareness of the possibility of conflict and the identity representations in mosque architecture is in line with Woodward's statement in her book, that crises because of a threat or a challenge to stability have made identity an important issue. ${ }^{35}$ Threats from the outsiders to the authority of a community's place were responded by displaying the elements that represent the identity of the community, both elements that are attributive such as colors and symbols of the organization, as well as elements that are substantively reflecting the views of the group. Personalization efforts through the elements of identity representation is a form of nonverbal communication to prevent the occurrence of conflict before it actually happened in one's place.

Furthermore, in line with the ambivalence and the dilemma indicated earlier in the visual analysis, another finding in the text

35 Woodward, Understanding Identity, p. xi. 
analysis is some internal dynamics within the Nabdliyin themselves regarding the issue of dealing with identity representation in their mosques. One example is the internal dynamic happened in the mosque M.3 as follows:

"So, the sign (the NU's logo) is to state the identity of Masjid anNuur as the mosque of NU people. Why? It is feared that in the future we could lost the mosque... However, there are pros and cons between us... pros and cons in the sense of... if we put the logo of the organization, we worried that other people won't come at all... that's what usually happened, right?... So we finally ask the opinion of the members of the Islamic Law Council of this mosque, "What do you think, Yat?", they answered, "Wow!" all of them gave us their pointing thumbs... all of them (showed the symbol of their agreement)...”36

These internal dynamics within the Nabdliyin occured due to the ambivalences between the needs to secure the identity of the mosques and the communities themselves, and the serious concern that the frontal identity representation might drive other people totally away from the mosques. These mixed feelings have resulted in the explicit yet ambiguous pattern of identity representations. Explicit in the sense of the direct use of the NU's organization logo as the main ornament on the mosques' façades; ambiguous in the sense of the intensity (only one or two per mosque), the placement (only on the exterior façades), and the absence of the the word "NU" which is an important part of the official logo.

The ambivalences found in the identity representation of these Nabdliyin mosques can be viewed in the relational characteristics of identity itself. Identity, according to Woodward, is relational. It is being constructed through relations of difference, such as 'us' and 'them'.37 In this case, besides the various differences that exist between these groups, there remain similarities that create a shared-identity among

\footnotetext{
36 The original version in Indonesian says: "Iadi itu untuk menyatakan babwa identitas masjid an-Nuur adalah masjidnya orang NU. Kenapa? dikhawatirkan ke depan itu nanti moromoro masjidnya moro ilang, itu yang dikhawatirkan... itupun sesunggubnya masih ada pro kontra ya, tapi ketika... pro kontra itu artinya gini lho... Ngko ojo-ojo ngko malih anu, lek ono, ono gambare malih wong ga gelem mlebu... biasae lak ngono ya... Terus akbirnya kita, kita datangkan Dewan Abkam, kita punya Dewan Abkam di susunan masjid, ada yang kbusus mengenai bukum. Kita tanyakan, Gimana Yai? 'Wo!” (mengacungkan jempol). Gini semua (mengacungkan jempol) dari delapan, dari empat, Dewan Abkam itu begini semua..."

37 Ibid., p. xii.
} 
them all as fellow Muslims. This sense of shared-identity is the reason why other people from other Islamic groups, even the ones deemed radical, are still accepted in the mosques even with some limitations and role restrictions. The other reason is the mosque institution itself has an obligation to serve all Muslims regardless of their groups and organizations.

\section{Conclusion}

To sum up, the expressions of power and authority occur not only in the major religious monuments such as grand mosques, but also in the community mosques with the specific local socio-political context, such as the dynamic interaction between Islamic groups. In general, the authority and the power of the ruling bodies are expressed in the form of the monumentality and the greatness of grand mosques' architecture. However, in the context of the community mosques, the authority and the power are expressed with the different strategies, due to the different backgrounds and purposes. The importance of the context of identity is stated clearly by Woodward, "Identity matters, but how and why it matters depends on time and place and on specific historical, social and material circumstances". 38

Therefore, this paper emphasizes the politics of identity representation in the community mosques where some physical and non-physical strategies have been taken by the stakeholders of six Nabdliyin mosques in Malang Raya, East Java, in order to defend spaces and prevent conflicts. Eventhough these strategies are vulnerable to possibilities of misunderstanding and different interpretations, apparently they tend to be depicted as one of the most appropriate ways to convey the messages without causing further open conflicts within the society. However, the external dynamics between groups on the one hand and the internal dynamics between members of the communities on the other hand have resulted in the use of the explicit yet ambivalent elements of identity representation. These ambivalences show that the identity representation phenomena in the Nabdliyin mosques are intended more as the prevention of conflict rather than an effort to make the mosques exclusive. Moreover, representing identity is considered as one way to maintain peace and tolerance

38 Ibid., p. vii. 
among Islamic groups, through which each group accepts and respects each other's roles in the mosques.

In these Nadhliyin mosques, explicit identity affirmation strategies are possible to be taken due to their clear historical and legal aspects of the mosques. The strong support from the surrounding community as well as the local figures is another important context of those mosques. Eventhough there are also some intervening conditions such as pragmatical reasons and internal dynamics, the explicit strategies are finally taken by the mosques' authority as an addition to other implicit physical and non-physical strategies. The combination between physical and non-physical strategies have made the identity of these mosques expressed stronger. Thus, the community hopes that the possibility of direct conflicts can be prevented, eventhough there could be some misinterpretations from other groups towards these mosques as exclusive and restricted for Muslims from other groups. []

\section{References}

Grabar, Oleg. "The Architecture of Power: Palaces, Citadels, and Fortifications." in George Michell (ed.). Architecture of the Islamic World: Its History and Social Meaning. London: Thames \& Hudson, 1978.

Holod, Renata and Hasan-Uddin Khan. The Mosques and the Modern World: Architects, Patrons, and Designs since the 1950s. London: Thames \& Hudson, 1997.

Ismail, Alice Sabrina and Mohd. Tajuddin Mohd. Rasdi. "Mosque Architecture and Political Agenda in Twentieth-century Malaysia." Journal of Architecture, 15, 2 (2010), pp. 137-152.

Kusno, Abidin. Bebind the Postcolonial: Architecture, Urban Space and Political Cultures in Indonesia. New York: Routledge, 2000.

-. "The Reality of One-which-is-Two" - Mosque Battles and Other Stories: Notes on Architecture, Religion, and Politics in the Javanese World." Journal of Arcbitectural Education, 57, 1 (2003), pp. 57-67.

Meerwein, G., B. Rodeck, and FH. Mahnke. Color - Communication in Architectural Space. Switzerland: Birkhäuser, 2007. 
Necipoglu, Gulru. "Anatolia and the Ottoman Legacy." Martin Frishman and Hassan-Uddin Khan (eds). The Mosque: History, Architectural Development \& Regional Diversity. London: Thames \& Hudson, 1994.

O’Neill, Hugh. "Diadem or Dome: Sovereignty and Transformation of the Mosque in Sumatera." Tectonic Dimension in Islamic Architectural Tradition in Indonesia, Proceedings of $3^{\text {rd }}$ International Symposium on Islamic Expression in Indonesian Architecture. Yogyakarta: Department of Architecture, Faculty of Civil Engineering and Planning Islamic University of Indonesia, 2000.

Popescu, Carmen. “Space, Time, Identity." National Identities, 8 (2006), pp. 189-206.

Prijotomo, Josef. Dari Lamin dan Bilik Pengakuan Dosa. Surabaya: Wastu Lanas Grafika, 2004.

Rijal, Najamuddin Khairur. "Respons Pemerintah Lokal terhadap Ancaman Terorisme Global: Kasus ISIS di Kota Malang." Jurnal Global \& Strategis CSGS Unair Surabaya, 10, 1 (2016), pp. 30-54.

Rijal, Syamsul. "Friday Prayer and an Indonesian Islamic Identity in Canberra, Australia." Journal of Indonesian Islam, 3, 1 (2009), pp. 148-167.

Roose, Eric. The Architectural Representation of Islam; Muslim-Commissioned Mosque Design in the Netherlands. Amsterdam: ISIM/Amsterdam University Press, 2009.

Saerozi, Muh. "From Controversi to Tolerance: Dynamics of the Development of Istiqomah Mosque in Front of a Church in Ungaran Central Java Indonesia." Journal of Indonesian Islam, 11, 2 (2017), pp. 423-458.

Şimşek, S., Z. Polvan, and T. Yeşilşerit. "The Mosque as a Divisive Symbol in the Turkish Political Landscape." Turkish Studies, 7, 3 (2006), p. 489-508.

Sudjic, Deyan. The Edifice Complex: How the Rich and Powerful Shape the World. London: Penguin Press, 2005.

Verkaaik, Oskar. Religious Architecture: Anthropological Perspectives. Amsterdam: Amsterdam University Press, 2013.

Woodward, Kath. Understanding Identity. London: Oxford University Press Inc., 2002. 